\title{
Nursing Research Priorities in Light of the Sustainable Development Goals: The 2030 Agenda
}

Prioridades de investigación de enfermería a la luz de los objetivos de desarrollo sostenible: agenda 2030 Prioridades de pesquisa de enfermagem à luz dos objetivos de desenvolvimento sustentável: agenda 2030

Maria Helena Palucci Marziale

\section{KEYWORDS (SOURCE: DeCS)}

Nursing research; public health; the 2030 agenda for sustainable development; sustainable development goals; health research agenda; health priority agenda; nursing.

\section{PALABRAS CLAVE (FUENTE: DECS)}

Investigación en enfermería; salud pública; agenda 2030 para el desarrollo sostenible; Objetivos de Desarrollo Sostenible; agenda de investigación en salud; agenda de prioridades en salud; enfermería.

\section{PALAVRAS-CHAVE (FONTE: DeCS)}

Pesquisa em enfermagem; saúde pública; agenda 2030 para o desenvolvimento sustentável; objetivos de desenvolvimento sustentável; agenda de pesquisa em saúde; agenda de prioridades em saúde; enfermagem.

DOI: 10.5294/aqui.2019.19.2.1

To reference this article / Para citar este artículo / Para citar este artigo

Palucci MH. Nursing Research Priorities in Light of the Sustainable Development Goals: The 2030 Agenda. Aquichan; 19(2): e1921. D0I: 10.5294/aqui.2019.19.2.1

1 orcid.org/0000-0003-2790-3333. Universidad de São Paulo, Brasil. marziale@eerp.usp.br 
The 2030 Agenda, adopted by the United Nations (1), is a global guide to action designed to transform the world based on sustainable development. It seeks to satisfy the needs of the current generation, without compromising the possibility that future ones can do the same. This road map strives for the eradication of poverty in all its forms and dimensions by promoting a dignified life for people and by strengthening universal peace. The 2030 Agenda is comprised of 17 sustainable development goals (SDGs) and 169 goals to be met by governments, businesses, academia and citizens. These goals combine the economic, social and environmental dimensions of sustainable development.

The Sustainable Health Agenda for the Americas: 2018-2030 (ASSA 2030) (2) was created in light of the specific characteristics of the Americas and is a call to action to improve health and wellbeing throughout the region. It includes regional public health challenges and has eleven goals; namely, 1) to expand equitable access to comprehensive quality health services that are centered on people, the family and the community, with an emphasis on health promotion and disease prevention; 2) to strengthen the office and governance of the national health authority and to promote social participation; 3) to reinforce the management and development of human resources in health; 4) to obtain adequate and sustainable financing for health, with equity and efficiency, and to advance towards protection against financial risks for all persons and their families; 5) to guarantee access to essential medicines, vaccines and other priority health technologies, according to the available scientific evidence and the national context; 6) to strengthen health information systems in support of the creation of policies and decision-making based on evidence; 7) to develop the capacity to generate, transfer and use evidence and knowledge in health, by promoting research, innovation and the use of technology; 8) to strengthen national and regional capabilities for preparedness, prevention, detection, surveillance and response to outbreaks of diseases and to emergencies and disasters that affect the health of the population; 9) to reduce morbidity, disability and mortality caused by non-transmittable diseases, injuries, violence and mental health disorders; 10) to reduce the burden of transmittable diseases and to eliminate unattended diseases that are ignored; and 11 ) to reduce inequality in health through cross-sector, multi-sector and regional approaches to the social and environmental determinants of health.

The contribution nurses make to compliance with the SDGs (1) and ASSA 2030 (2) is significant, since they are part of an effective system of health care that is essential to shape the development of the workforce in the field and to rationalize the various demands for health care. Therefore, it is necessary to adopt action in interprofessional education and collaborative practice, to assess human resources, and to improve working conditions and local health systems. In other words, this means schools must train nurses who are qualified in advanced nursing practices (3).

An extensive study done by the team of the Pan American Health Organization's regional advisor on nursing and health technicians (4) identifies the region's priorities in terms of research in nursing for the promotion of universal access to health care and its universal coverage: policies and training for human resources in nursing; the structure, organization and dynamics of health systems and services; science, technology, innovation and information systems in public health; financing for health systems and services; and health policies, governance and social control and social studies in the field of health.

PAHO will launch a document in May 2019 outlining strategic actions for nursing aimed at the Americas region. These lines of action are designed to strengthen and consolidate nursing leadership and strategic management in the context of health systems and in policy formulation and monitoring; to address the working conditions and capabilities of nurses to expand universal health-care access and coverage with equity and excellence, and to strengthen the quality of nursing education to respond to the needs of universal access and coverage in terms of health systems and the SDGs (1).

There is currently no global agenda for research priorities in nursing. However, the Ribeirão Preto School of Nursing at the University of São Paulo (Brazil), which is a collaborating center of the Pan American Health Organization (PAHO) / World Health Organization (WHO), has been tasked with helping to implement a regional agenda of priorities in nursing research for Latin America and the Caribbean. Accordingly, it hopes to count on collaboration from the nursing schools and the researchers in graduate programs throughout the countries of the region.

The hope is that nurse researchers will be able to help meet the goals in national and international agendas through studies that result in strong scientific evidence. We nurses play a very important role in health care: we make a difference in the lives of people and in services. We should be extremely proud of that and must continue in our quest to conquer ever broader areas. 


\section{References}

1. Nações Unidas. Transformar nuestro mundo: la Agenda 2030 para el Desarrollo Sostenible. Seventieth Session of the UN General Assembly, Resolution A/RES/70/1 [Internet]. Available from: https://documents-dds-ny.un.org/doc/UNDOC/GEN/N15/291/93/PDF/N1529193.pdf?OpenElement

2. Organización Panamericana de la Salud. Agenda de salud sostenible para las Américas 2018-2030: un llamado a la acción para la salud y el bienestar en la región. Washington, DC, EUA [Internet] [cited 2017 Sept.]. Available from: https://www. paho.org/hq/index.php?option=com_content\&view=article\&id=13246:health-agenda-americas\&Itemid=42349\&lang=es

3. Darzi A, Evans T. The global shortage of health workers: an opportunity to transform care. Lancet [Internet]. 2016 [cited 2019 Feb. 10];388(10060): 2576-77. DOI:10.1016/S0140-6736(16)32235-8

4. Cassiani-Silvia HdB, Bassalobre-Garcia A, Reveiz L. Acceso universal a la salud y cobertura universal de salud: la identificación de prioridades de investigación en la enfermería en América Latina. Rev. Latino Am. Enfermagem [Internet]. 2015 Dec. [cited 2019 Feb.];23(6):1195-1208. DOI:10.1590/0104-1169.1075.2667 